\title{
Kuorittu ja kuoreton kaura turkiseläinten rehussa
}

\author{
Nita Nenonen ${ }^{1)}$, Jarmo Valaja ${ }^{2)}$ ja Ilpo Pölönen ${ }^{3)}$ \\ ${ }^{1)}$ Maa- ja elintarviketalouden tutkimuskeskus/Turkistalous, Turkistie 8, 69100 Kannus, \\ nita.nenonen@mtt.fi \\ ${ }^{2)}$ Maa- ja elintarviketalouden tutkimuskeskus/Eläinravitsemus, \\ 31600Jokioinen,jarmo.valaja@mtt.fi \\ ${ }^{3)}$ Suomen Turkiseläinten Kasvattajain Liitto ry, PL 5, 01601 Vantaa, ilpo.polonen@stkl-fpf.fi
}

\section{Johdanto}

Ohraan verrattuna kaurassa on sekä rehuarvoa parantavia että heikentäviä ominaisuuksia. Kaura sisältää vähemmän liukoista kuitua kuin ohra eikä näin ollen aiheuta ulosteongelmia. Kaurassa on myös enemmän rasvaa kuin ohrassa tai vehnässä. Vaikka kauran kuidulla on hyviä ominaisuuksia, suuri kuoripitoisuus kuitenkin heikentää kauran rehuarvon muita viljoja alemmaksi.

Kuorettoman kauran rasvapitoisuus on jopa $7 \%$ kun se muilla viljalajeilla on alle 3\%. Paitsi viljelemällä, energiapitoista kauraa saadaan myös kuorimalla kauran jyvä koneellisesti. Koska rehuarvoltaan lähes nollan arvoisen kuoren osuus kaurassa on yli $20 \%$, kuorinta nostaa kauran energia-arvoa viidenneksellä. Kuoritun kauran rasvapitoisuus voi olla jopa $8 \%$.

Tutkimuksen tavoitteena oli selvittää kuoritun ja kuorettoman kauran soveltuvuutta turkiseläinten rehuun. Tutkimuksessa selvitettiin kuoritun ja kuorettoman kauran tuotantovaikutuksia kasvavilla minkeillä ja siniketuilla alku- sekä loppukasvatuksen aikana. Lisäksi selvitettiin minkeillä ja siniketuilla kauralisäyksen vaikutuksia rehun sulavuuteen.

\section{Aineisto ja menetelmät}

Tutkimukset toteutettiin Maa- ja elintarviketalouden tutkimuskeskuksen (MTT) turkistutkimusasemalla Kannuksessa 17.7.-10.12.2001. Tutkimus jakaantui varhaiskasvun- ja tuotantokauden kokeeseen minkillä ja siniketulla.

\section{Varhaiskasvun koe}

Varhaiskasvun kokeissa oli 140 minkkiä ja 140 sinikettua, jotka kaikki olivat uroksia. Koe alkoi vieroituksen jälkeen ja kesti seitsemän viikkoa. Koemallina oli jatkuva kasvatuskoe ja ryhmiä oli seitsemän. Koerehuissa kypsä ohra korvattiin asteittain raa'alla kuorettomalla tai kuoritulla kauralla:

1. Ohra 15\% Rehussa $15 \%$ kypsää ohraa (kontrolli)

2. Kuoreton 5\%: Rehussa 5\% raakaa kuoretonta kauraa ja 10\% kypsää ohraa

3. Kuorittu 5\%: Rehussa 5\% raakaa kuorittua kauraa ja 10\% kypsää ohraa

4. Kuoreton $10 \%$ : Rehussa $10 \%$ raakaa kuoretonta kauraa ja $5 \%$ kypsää ohraa

5. Kuorittu 10\%: Rehussa $10 \%$ raakaa kuorittua kauraa ja 5\% kypsää ohraa

6. Kuoreton 15\%: Rehussa 15\% raakaa kuoretonta kauraa, ei ohraa

7. Kuorittu 15\%: Rehussa 15\% raakaa kuorittua kauraa, ei ohraa

Kuoritun kauran partikkelikoko oli $2 \mathrm{~mm}$ ja ohran sekä kuorettoman kauran partikkelikoko oli $4 \mathrm{~mm}$. Muina raaka-aineina käytettiin silakkaa, broilersivutuotetta, kalajauhoa, melassileikettä, soijaöljyä ja hiven- sekä vitamiiniseosta. Rehut optimoitiin kasvavien kettujen ja minkkien tarpeiden mukaan ja ne sisälsivät n. $36 \%$ valkuaista ME:stä.

Rehunkulutus mitattiin häkeittäin. Eläimet punnittiin kokeen alussa ja lopussa sekä kokeen aikana kahden viikon välein

Sulavuuskoe tehtiin 70 eläimelle neljännellä ja viidennellä koeviikolla. Sulavuuskokeessa ravintoaineiden sulavuudet määritettiin epäsuoralla menetelmällä käyttäen ns. merkkiainemenetelmää.

\section{Tuotantokauden koe}

Tuotantokauden kokeessa oli 180 minkkiä ja 180 sinikettua, joista puolet olivat uroksia ja puolet naaraita. Eläinten ikä oli kokeen alussa noin 3-3.5 kuukautta. Koemallina oli jatkuva kasvatuskoe ja ryhmiä oli kolme. Koerehuissa kypsä ohra korvattiin asteittain raaálla kuoritulla kauralla. Kuoritun kauran partikkelikoko oli $4 \mathrm{~mm}$.

1. Ohra 16\%: Rehussa $16 \%$ esikypsytettyä ohraa (kontrolli)

2. Kaura $8 \%$ : Rehussa $8 \%$ raakaa kuorittua kauraa ja $8 \%$ esikypsytettyä ohraa

3. Kaura 16\%: Rehussa $16 \%$ raakaa kuorittua kauraa.

Muina raaka-aineina käytettiin silakkaa, broilersivutuotetta, kalajauhoa, melassileikettä, soijaöljyä, metioniinia ja hiven- sekä vitamiiniseosta. Rehut optimoitiin kasvavien kettujen ja minkkien tarpeiden 
mukaan ja ne sisälsivät n. 29 \% valkuaista ME:stä.

Eläimet punnittiin kokeen alussa ja lopussa sekä kokeen aikana kahden viikon välein.

Kokeen lopussa eläimet lopetettiin sähköllä ja nahkottiin. Nahkat punnittiin, mitattiin ja arvosteltiin Turkistuottajat Oy:ssä. Väri, massa, puhtaus, peittävyys ja laatuluokka arvosteltiin Turkistuottajat Oyj:n lajittelijoiden toimesta asteikolla 1-10 (10 paras).

\section{Tulokset}

\section{Varhaiskasvun koe}

\section{Sulavuuskoe ja rehunkulutus, minkki}

Rasvan sulavuus oli yhtäläinen kaikissa seitsemässä rehussa (90.2-91.6 \%). Kuoritun ja kuorettoman kauran ryhmissä rehun kuiva-aineen, orgaanisen aineen, rasvan, valkuaisen ja hiilihydraatin sulavuudet eivät eronneet tilastollisesti ohraryhmän vastaavista ravintoaineiden sulavuuksista. Kun kuoritun kauran osuus rehussa lisääntyi, kuiva-aineen, orgaanisen aineen, valkuaisen ja hiilihydraattien sulavuudet paranivat. Rehunkulutus g/vrk oli yhtäläinen kaikilla ryhmillä.

\section{Sulavuuskoe ja rehunkulutus, sinikettu}

Rehunkulutuksessa g/vrk ei ollut eroja ryhmien välillä. Rehunkulutus g KA/vrk sen sijaan oli alhaisin ryhmässä kuorittu kaura $5 \%(\mathrm{p}<0.01)$. Vaikka ryhmän kuorittu kaura $5 \%$ rehunkulutus oli alhaisempi kuin rehunkulutus muissa ryhmissä, ryhmän sinikettujen kasvu ei eronnut tilastollisesti muiden ryhmien sinikettujen kasvuista.

Kuoritun ja kuorettoman kauran ryhmissä rehun kuiva-aineen, orgaanisen aineen ja rasvan sulavuudet olivat yhtäläisiä ohraryhmän (ohra $15 \%$ ) vastaavien sulavuuksien kanssa. Valkuaisen sulavuus oli parempi kuorettoman ja kuoritun kauran (kauraa 15\%) ryhmissä kuin ohraryhmässä (kaura 0\%). Ohraryhmässä (ohra 15\%) pelkästään hiilihydraattien sulavuus oli parempi kuin kauraryhmissä (kuoretonta ja kuorittua kauraa 15 \%). Rasvan sulavuus oli yhtäläinen kaikissa rehuissa (sulavuudet 91.3-92.8 \%). Sulavuus parani kun kuorettoman kauran osuus rehussa lisäänty. Ohran (ohra 15\%) sulavuudet eivät eronneet kuorettoman kauran ryhmien sulavuuksista (kuoreton kaura 5, 10 ja 15 \%). Kuoritun kauran sulavuudet olivat yhtäläisiä ohraryhmän kanssa muiden paitsi tuhkan sulavuuden kanssa.

\section{Tuotantokauden koe}

\section{Kasvu ja nahkaparametrit, minkki}

Minkkien painonkehityksessä ei ollut tilastollisesti merkitseviä eroja marraskuun alkuun mennessä. Marraskuun lopusta (21.11.) alkaen ryhmän kaura 8\% eläimet kasvoivat paremmin kuin ohraryhmän (ohra 16\%) eläimet ( $\mathrm{p}<0.05$ ). Ryhmän ohra 16\% (keskipaino kokeen lopussa $1981 \mathrm{~g}$ ) painonkehitys oli heikompaa kuin kaura 8 \% ryhmässä (keskipaino kokeen lopussa 2139 g). Kauraryhmien 8 ja $16 \%$ eläimet kasvoivat yhtäläisesti (2058 g ja 2139 g). Kokeen aikana suhteellinen kasvunopeus (SGR, $\% / v r k)$, kasvu kokeen aikana (g) ja vuorokautinen kasvu (g/vrk) oli tilastollisesti heikompaa ryhmässä ohra $16 \%$ kuin ryhmissä kaura 8 ja $16 \%$. (kuva 1 )

Minkkien nahkojen pituudessa, painossa ja laatuparametreissä ei ollut eroja ryhmien välillä.

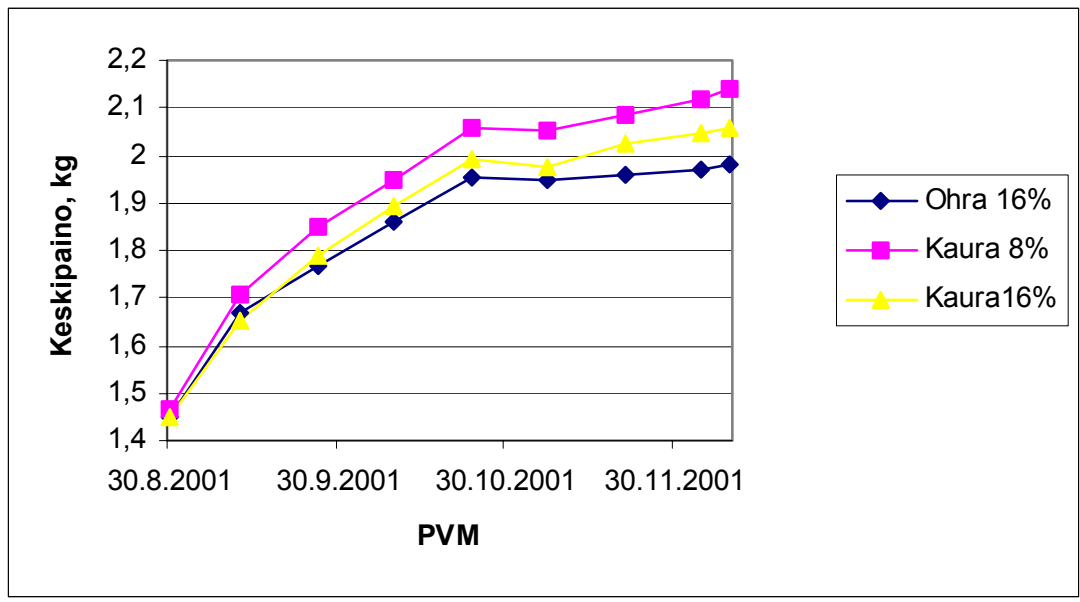

Kuva 1. Minkkien häkkikeskipainot $(\mathrm{kg})$ kokeen aikana, tuotantokauden koe 


\section{Kasvu ja nahkaparametrit, sinikettu}

Eläimet kasvoivat tasaisesti kaikissa ryhmissä. Häkkikohtaisissa keskipainoissa kokeen aikana, vuorokausikasvussa, suhteellisessa kasvunopeudessa (\%/vrk) ja kasvussa (g) kokeen aikana ei ollut tilastollisesti merkitseviä eroja.

Nahkojen pituudessa, painossa, massakkuudessa, värin puhtaudessa, laatuluokassa ja värissä ei ollut tilastollisesti merkitseviä eroja. Nahkojen keskipituudet olivat $125.8-127.0 \mathrm{~cm}$ ja keskipainot olivat 737.7 - 751.2 g. Peittävyys oli paras ryhmässä kaura $8 \%(5.1)$ ja huonoin ryhmässä kaura $16 \%$ (4.5).

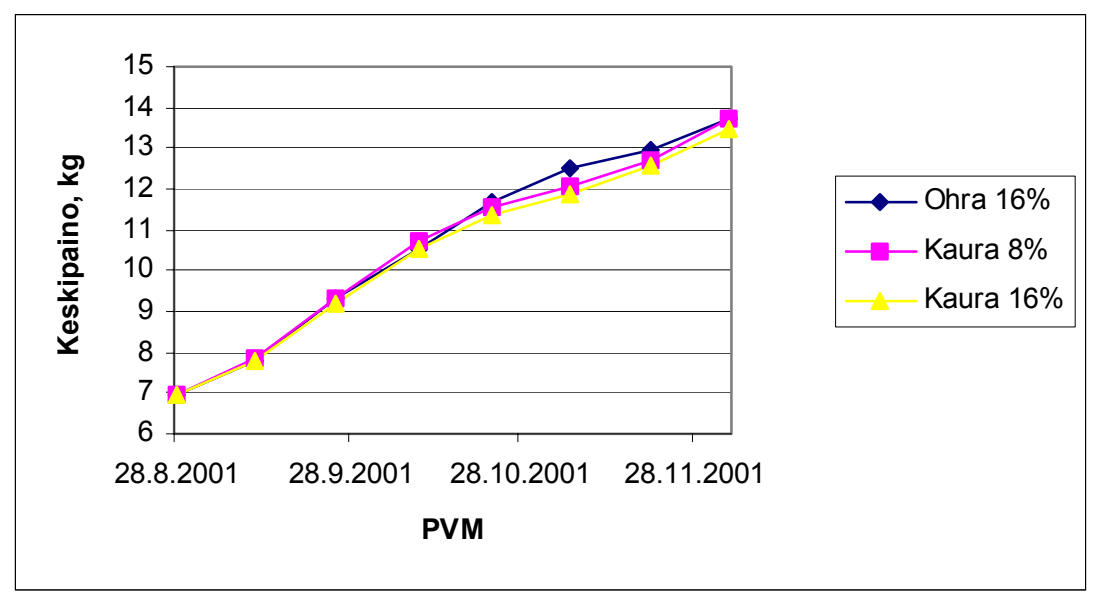

Kuva 2. Sinikettujen keskipainot $(\mathrm{kg})$ kokeen aikana, tuotantokauden koe

\section{Tulosten tarkastelu}

Kauran runsas kuitumäärä sitoo muita ravinteita, lisää ruokasulan viskositeettia ja nopeuttaa ruokasulan kulkua. Käytettäessä kuorittua tai kuoretonta kauraa voidaan eliminoida kuidun aiheuttamat negatiiviset vaikutukset ravintoaineiden sulavuuteen ja ruuansulatuselimistön toimintaan (Lewis et al. 1994, Meyer ja Zentek 1998). Kauran kuoriminen mekaanisesti tai kuorettoman kauran käyttö vähentää kauran kuitupitoisuutta ja siten parantaa kauran rehuarvoa huomattavasti. Kuorinnan vaikutus kauran rehuarvoon onkin suurempi kuin erilaisten kypsennyskäsittelyiden (Kempe ja Saastamoinen 2003). Myös kauran tärkkelyksen ohutsuolisulavuus on tutkimuksissa todettu paremmaksi kuin esim. ohran ja maissin. Käsittelemättömän kauran tärkkelys sulaa koiran ohutsuolessa 80-90 \%:sti, kun taas jauhetun ohran sulavuus on vain $30 \%$ (Gibbs et al. 1996, Meyer ja Zentek 1998).

Varhaiskasvun kokeen osakokeena suoritettu sulavuuskoe osoitti, että siniketulla sekä minkillä raaka kuorittu ja kuoreton kaura ovat erinomaisia rehun raaka-aineita, joiltakin osin jopa parempia kuin esikypsytetty ohra. Siniketuilla rehun ravintoaineiden sulavuudet olivat korkeita, hiilihydraattien sulavuus oli hieman alhaisempi kaura- kuin ohrarehuissa. Ketunrehun raaka-aineena käytettävän kauran kypsentäminen ei kuitenkaan paranna hiilihydraattien sulavuutta (Kiiskinen et al. 1988b). Minkkien sulavuuskokeessa raaka kuoreton ja kuorittu kaura olivat täysin kypsän ohran veroisia raaka-aineita.

Siniketun ja minkin varhaiskasvun kokeessa kaurarehujen valkuaisen sulavuus oli erinomainen. Siniketun osalta valkuaisen sulavuus oli parempi kaurarehuissa kuin ohrarehussa (ohra 15\%). Myös koirien ravitsemuskokeissa on havaittu, että kauran sulavan valkuaisen määrä on suurempi ja raakavalkuaisen sulavuus on kuoritussa kaurassa parempi kuin vehnässä, ohrassa tai maississa (Kempe ja Saastamoinen 2002). Kaurassa on muita viljoja tasapainoisempi aminohappokoostumus ja siten kuoreton ja kuorittu kaura ovat erinomaisia turkiseläinrehu raaka-aineita. Esimerkiksi kuorettoman kauran metioniini- ja tryptofaanipitoisuudet ovat samaa luokkaa kuin eläinperäisissä valkuaisraaka-aineissa liha- ja kalajauhossa (Case et al. 1995, Tuori et al. 1996).

Rasvan sulavuus oli samaa tasoa kaikissa rehuissa sekä minkkien että sinikettujen sulavuuskokeessa. Ravitsemuksellisesti kaurassa on merkittävää rasvojen monityydyttämättömyys ja suuri välttämättömien rasvahappojen (linoli- ja linoleenihappo) määrä. Välttämättömät rasvahapot vaikuttavat edullisesti karvapeitteen kuntoon.

Tuotantokauden kokeessa minkit ja siniketut kasvoivat hyvin. Siniketturyhmien välille ei muodostunut painoeroja kokeen aikana. Minkkiryhmissä kuorettoman kauran ryhmien eläimet 
painoivat enemmän kuin kontrolliryhmän (ohra 16\%) eläimet. Minkit pystyivät käyttämään tehokkaasti hyväksi kuorettoman kauran ravintoaineita -tehokkaammin kuin kypsän ohran ravintoaineita.

Raa'an kauran yhdenvertaisuus rehun raaka-aineena ohran rinnalla oli havaittavissa myös nahkojen koossa ja laadussa. Nahkat olivat samankokoisia ja -laatuisia kaikissa ryhmissä sekä minkillä että siniketulla

Varhaiskasvun- ja tuotantokauden kokeessa rehun runsaasta viljapitoisuudesta huolimatta ulosteongelmia ja huomattavaa pohjaverkkojen likaantumista ei esiintynyt. Raa'an kauran hyväksikäyttökyky koiraeläimillä on hyvä. Esimerkiksi koirilla ilmenee tahmaisia ulosteita vasta kun rehuun lisätään 50 \% raakaa kauraa (Kempe et al. 2001). Eläinten terveydentila oli hyvä molempien kokeiden ajan.

Kaurankuoria voidaan hyödyntää tulevaisuudessa erityisrehuihin, esim. supikoirien ja siitoseläinten rehuihin. Kauran kuitu tuottaa eläimen kannalta välttämättömiä lyhytketjuisia rasvahappoja ja tehostaa veden sekä suolojen imeytymistä paksusuolesta, sekä vahvistaa kylläisyydentunnetta.

\section{Johtopäätökset}

Varhaiskasvun ja tuotantokauden kokeiden tulokset -sekä ravintoaineiden sulavuudet, eläinten kasvunseuranta sekä nahkojen laatuparametrit- osoittavat, että kuorittu ja kuoreton kaura soveltuvat erinomaisesti turkiseläinten rehun raaka-aineiksi. Kokeessa ei ilmennyt mitään, mikä estäisi kuoritun ja kuorettoman kauran käytön turkiseläinten rehun raaka-aineena. Mikäli kuorettoman ja kuoritun kauran tuotantokustannukset pysyvät riittävän alhaisina, kuorittu ja kuoreton kaura ovat kilpailukykyisiä kotimaisia raaka-aineita, jotka eivät vaadi kypsentämistä.

\section{Kirjallisuus}

Case, L.P., Carey, D.P. ja Hirakawa, D.A. 1995. Canine and feline nutrition. A resource for companion animal professionals. Mosby -year Book, Inc. St.Louis, Missouri.

Gibbs, P.G., Potter, G.D., Schelling, G.T., Kreider, J.L. ja Boyd, B.L. 1996. The significance of small vs large intestinal digestion of cereal grain and oilseed protein in the equine. J. Equine Sci. 16:60-65.

Lewis, L.D., Magerkurth, J.H., Roudebush, P., Morris, M.L., Mitchell, E.E. ja Teeter, S.M. 1994. Stool characteristics, gastrointestinal transit time and nutrient digestibility in dogs fed different fiber sources. J. Nutr. 124: 2716S-2718S.

Meyer, H. ja Zentek, J. 1998. Ernährung des Hundes: Grundlagen, Futtering, Diätetik. 3rf ed. Berlin/Wien, Blackwell Wissenschafts-Verlag. 314p.

Kempe, R. ja Saastamoinen, M. 2003. Composition, digestibility and nutritive value of cereals for dogs. Käsikirjoitus.

Kempe, R. ja Saastamoinen, M. 2002. Kypsennetyn ohran ja kuoritun kauran sulavuus koirilla. Loppuraportti/Maa- ja elintarviketalouden tutkimuskeskus, Kotieläintuotannon tutkimus, Hevostalous, Ypäjä.

Kempe, R., Särkijärvi, S., Saastamoinen, M., Ahtila, L. ja Kommeri, U. 2001. Kaura hevosten ja koirien ruokinnassa ja rehujen raaka-aineena. Loppuraportti/ Maa- ja elintarviketalouden tutkimuskeskus, Kotieläintuotannon tutkimus, Hevostalous, Ypäjä.

Kiiskinen, T. ja Mäkelä, J. 1988. Kasviperäisten valkuaisrehujen sulavuus minkeillä. Maatalouden tutkimuskeskus. Tiedote $5 / 88$.

Kiiskinen, T., Mäkelä, J. ja Rouvinen, K. 1988. Eri viljalajien sulavuus minkillä ja siniketulla. Maatalouden tutkimuskeskus. Tiedote 5/88.

Tuori, M., Kaustell, K., Valaja, J., Aimonen, E., Saarisalo, E. ja Huhtanen, P. 2001 Rehutaulukot ja ruokintasuositukset 2001 [verkkodokumentti]. Jokioinen: MTT. Julkaistu 2.4.2001. Saatavissa Internetissä: http://www.mtt.fi/julkaisut/rehutaulukot. 